American Journal of Applied Sciences 8 (5): 472-480, 2011

ISSN 1546-9239

(C) 2010 Science Publications

\title{
Comparing the Fertility of Soils under Khaya ivorensis Plantation and Regenerated Degraded Secondary Forests
}

\author{
${ }^{1}$ Yetti Heryati, ${ }^{1,2}$ Arifin Abdu, ${ }^{3}$ Mohd Noor Mahat, ${ }^{1,2}$ Hazandy Abdul-Hamid, \\ ${ }^{4}$ Shamshuddin Jusop, ${ }^{1}$ Nik Muhamad Majid, ${ }^{1}$ Ika Heriansyah, \\ ${ }^{1}$ Leslie Ajang and ${ }^{5}$ Khairulmazmi Ahmad \\ ${ }^{1}$ Department of Forest Management, Faculty of Forestry, \\ ${ }^{2}$ Laboratory of Sustainable Bioresource Management, \\ Institute of Tropical Forestry and Forest Products, \\ ${ }^{4}$ Department of Land Management, Faculty of Agriculture, \\ University Putra Malaysia, 43400 UPM Serdang, Selangor, Malaysia \\ ${ }^{3}$ Forest Research Institute Malaysia, 52109 Kepong, Malaysia \\ ${ }^{5}$ Department of Crop Science, Faculty of Agriculture and Food Sciences, \\ University Putra Malaysia Bintulu Sarawak Campus, 97008 Bintulu, Sarawak
}

\begin{abstract}
Problem statement: It is widely accepted that conversion of natural forest to other land use types leads to deterioration of soil fertility and increased soil compaction which consequently become degraded secondary forests. Degraded secondary forest or forestland is indicated by low in soil fertility and organic matter due to imbalance input and output from original vegetation. Forest plantation through planting fast growing exotic species is usually implemented to curtail degradation of secondary forest or forestland and improve the soil fertility through organic matter accumulation. However, fundamental information on degraded forestland being converted to forest plantation using exotic species such as Khaya ivorensis is not available. The objectives of this study were: (1) to characterize the properties of three degraded soils under rehabilitation using K. ivorensis; and (2) to evaluate their fertility status by Soil Fertility Index (SFI) and Soil Evaluation Factor (SEF). Approach: This study was concentrated on three soil series (Rengam, Durian and Padang Besar) found under $K$. ivorensis plantation and at the adjacent secondary forest in Segamat, Johor, Malaysia. To characterize and evaluate the soil fertility status for each soil series, three plots $(30 \times 40 \mathrm{~m})$ were randomly established on each soil series. Soils for each series were sampled at the depth of 0-10 cm (surface soil) and $20-30 \mathrm{~cm}$ (subsurface soil). They were randomly collected at six different points for each replicate. Soil analyses were carried out accordingly. Results: The soils both in planted and secondary forests were moderately acidic to slightly acidic with low content of exchangeable bases and available $\mathrm{P}$ but high in $\mathrm{Al}$ saturation. The Rengam series under $K$. ivorensis plantation contained higher total carbon and clay compared with those of Padang Besar and Durian series. Clay and total carbon contents were highly correlated with the Cation Exchange Capacity (CEC), indicating the potential of negative charge produced by the clay and organic playing an important role in supplying and holding plant nutrients. The SFI result revealed that soil fertility status of Rengam soil was significantly higher than the other two soil series. There was no significant difference observed for SEF. Based on SFI and SEF values, there were no significant differences of fertility status between the planted and secondary forests for both soil depths. Conclusion: This study revealed that Rengam soil is more fertile than the other two soils. Using SFI and SEF it can be concluded that fast growing exotic species of $K$. ivorensis has the potential to improve site productivity and soil fertility.
\end{abstract}

Key words: Exotic species, Khaya ivorensis, degraded forestland, secondary forest, soil fertility, soil series, soil organic matter, soil sampling, Soil Fertility Index (SFI), Soil Evaluation Factor (SEF)

Corresponding Author: Arifin Abdu, Department of Forest Production, Faculty of Forestry, Universiti Putra Malaysia, 43400 UPM Serdang, Selangor, Malaysia Tel: +603-89467177 Fax: +603-89432514 
Am. J. Applied Sci., 8 (5): 472-480, 2011

\section{INTRODUCTION}

Globally, most of tropical forest in the world decline due to deforestation (Montagnini et al., 1997; FAO, (2005). The decrease reaches a rate of 16.9 million hectares annually. In Malaysia, the decrease in forest area is caused by deforestation reaching 1,486,000 hectares annually between 1990 and 2005; this indicates that Malaysian forest cover had lost about $6.64 \%$ (FAO, 2005). Deforestation leads to decline in soil fertility, which is indicated by a decrease in soil organic matter due to an imbalance between the input and output of carbon and other nutrients that originate from vegetations. Moreover, most of soils in the tropical forest are infertile (Jordan, 1989), while deforestation can disturb nutrient cycling process, so that nutrient can be rapidly lost.

Forest rehabilitation through plantation forestry is important not only for meeting wood demands, but also as a method that can restore degraded soils resulting from deforestation (Parotta, 1992; Parotta et al., 1997 and Lugo, 1997; Zaidey et al., 2010). Forest plantation is regarded as one of the methods to turn forest into more productive areas by means of reverting the soil fertility and reducing soil erosion. Plantation forest plays an important role in providing and holding nutrients in soils and maintaining their structures. Soils have a role to meet the diverse needs of plant life, such as mechanical support and the establishment of roots, provide air (oxygen) for respiration, provides water and nutrients and as a medium of interaction between the plants with soil.

Soil organic matter tends to change continuously by anthropogenic factor such as deforestation. However, Bowyer (2005) stated that with increasing interest worldwide in forest plantations, concerns about the potential environmental impacts of establishing forest plantations on a large scale are increasing as well. Specific concerns focus on potential loss of soil fertility and productivity under short harvest rotations. Therefore, research that can form the basis for selection of stands for planting on a particular environment is needed. This is to anticipate the occurrence of land degradation as a result of planting a particular species and also to determine the necessary actions, thus gaining optimal production (Bowyer, 2005). As we have known, some of species can accelerate soil acidity which tends to lower soil cation exchange capacity and also further accelerate the decline in $\mathrm{Ca}$ and $\mathrm{Mg}$ content of the soils. However, some tree species such as the family Leguminosae have trait that support towards improving the condition and productivity of the land. Similarly, Hamzah et al. (2009) found that rehabilitating degraded forestland with dipterocarp and non dipterocarp species had improved both soil nutrients and valuable timber stock in Pasoh, Peninsular Malaysia. The related studies Moran et al. (2000) in Lu et al. (2002) also stated that successional forests play an important role in soil restoration through accumulation of biomass, build-up of litter and organic matter and other beneficial soil/plant interactions. Soil fertility, physical structure and land use history are the most important aspects affecting vegetation growth in the Amazon basin ( $\mathrm{Lu}$ et al. 2002). Therefore, to maintain the soil fertility of degraded forestland, the selection of species must be taken into consideration. This is to avoid the possibility of accelerating acidity and nutrient depletion due to intensive land use. This case might occur in agriculture or in forest, in particular forest plantation.

K. ivorensis is one of exotic species from Africa that have high adaptability on degraded forestland in Malaysia. This species is recommended as forest plantation to meet the needs of timber industry in Malaysia. Several studies of $K$. ivorensis growing on different soil type concerned with growth performance (Appanah and Weinland, 1993; Jeyanny et al., 2009; Yetti et al., 2011), but assessment of soil properties is not done or at most limited. The objectives of this study were: 1) to characterize the properties of three degraded soils under rehabilitation using K. ivorensis; and 2) to evaluate their fertility status by soil fertility index (SFI) and soil evaluation factor (SEF). This study is important as a reference for development of forest plantation using $K$. ivorensis.

\section{MATERIALS AND METHODS}

Study site description: The study was conducted at the FRIM Research Station in Segamat, Johor, Malaysia. The station located about $250 \mathrm{~km}$ from Kuala Lumpur. Generally, the mean annual temperature and humidity are $27^{\circ} \mathrm{C}$ and $94 \%$, respectively. The mean annual rainfall from 2004-2008 was $2508 \mathrm{~mm} /$ year. The topography is flat to undulating. Based on the United States Department of Agriculture soil taxonomy, the three soil series (Rengam, Durian and Padang Besar) at the study site are classified as Ultisols which are the most widespread soil order in Peninsular Malaysia (Paramananthan, 2000). The location of Rengam series is $02^{\circ} 34^{\prime} 683 \mathrm{~N} ; 102^{\circ} 58^{\prime} 643 \mathrm{E} ; 82 \mathrm{~m}$ above sea level (a.s.l.), the Durian series is $02^{\circ} 34^{\prime} 927 \mathrm{~N} ; 102^{\circ} 58^{\prime} 678$ E; $74 \mathrm{~m}$ a.s.l. and the Padang Besar series is $02^{\circ} 34^{\prime}$ $908 \mathrm{~N} ; 102^{\circ} 58^{\prime} 725 \mathrm{E} ; 78 \mathrm{~m}$ a.s.l. 
Planting history of $\boldsymbol{K}$. ivorensis: $K$. ivorensis is a promising exotic tree species in the forest plantation program in Malaysia (Appanah and Weinland, 1993). The species belongs to the family Meliaceae, which is one type of African mahoganies. It was initially in the States of Kedah and Selangor in Malaysia in the late 1950 's and early 1960's and has adapted well to the local climatic conditions. It was selected by the Malaysian Timber Industry Board as one of eight species targeted for large-scale planting in Malaysia in 1992.

The Forest Research Institute Malaysia (FRIM) had established of K. ivorensis plantation in Segamat, Johor in 2004 as a sample area for future forest plantation development. The species was planted on different soils such as the Rengam, Durian and Padang Besar series using small scale land clearing and monoculture system (Yetti et al., 2011). The initial planting spacing was $4 \mathrm{~m} \times 3 \mathrm{~m}$. All of the plants were applied with the same dosage of fertilizer from early planting for three years. The treatment during cultivation was fertilizer $200 \mathrm{~g}$ of CIRP (Christmas Island Rock Phosphate) fertilizer/tree; after cultivation, $500 \mathrm{~g}$ of organic fertilizer/tree was applied every six months until the plant were three years old. Weeding was done once every three months.

Soil sampling and analyses: Soil samples were collected from three soil series (Rengam, Durian and Padang Besar) which were under five-year-old $K$. ivorensis plantation and the adjacent secondary forest. To evaluate soil fertility in each soil series and adjacent secondary forest, we were collected soil samples at the depths of $0-10 \mathrm{~cm}$ (surface soils) and 20-30 cm (subsurface soils) in three replicates for each soil series. For each soil, soil samples from the same soil depth at six points were collected randomly within each replicates, representing 18 samples for both depths at each soil series. The soil samples were air-dried for two to four days and crushed manually and sieves to pass 2 $\mathrm{mm}$ mesh sieve. The particle-size distribution was determined by the pipette method. The method consists of preliminary destruction of the organic matter by heating with the hydrogen peroxide. Adsorbed cations were removed by treating the samples with $0.2 \mathrm{M}$ hydrochloric acid and dispersed with calgon. The sand $(50-2000 \mu \mathrm{m})$ was separated by the sieving process whereas silt $(2-50 \mu \mathrm{m})$ and clay $(<2 \mu \mathrm{m})$ were determined by the pipette method. The USDA system was used for the textural classification. To determine soil bulk density, undisturbed core soil samples taken with core ring of size $76 \mathrm{~mm}$ in diameter and $40 \mathrm{~mm}$ in height. The samples weight were recorded and put in the oven at $105^{\circ} \mathrm{C}$ for 24 hours. Bulk density was expressed in $\mathrm{g} \mathrm{cm}^{-3}$ on a dry weight basis. The moisture contents were expressed in volumetric $(\mathrm{v} / \mathrm{v})$ basis according to the following equation, $\Theta(\mathrm{v} / \mathrm{v})=\Theta(\mathrm{w} / \mathrm{w})$ $\mathrm{x}$ bulk density $/ \mathrm{\rho w}$, where $\Theta(\mathrm{v} / \mathrm{v})=\%$ moisture contents on volume basis; $\Theta(\mathrm{w} / \mathrm{w})=\%$ moisture contents on weight basis; and $\mathrm{pw}=$ density of water.

Soil $\mathrm{pH}$ was determined in water and $1 \mathrm{M} \mathrm{KCl}$ solution with 1: 2.5 ratio of soil to solution. Soil $\mathrm{pH}$ in water was measured after shaking for one minute and leaving the suspension to equilibrate overnight. The $\mathrm{pH}-\mathrm{KCl}$ was measured after 10 minutes of shaking. Total carbon and nitrogen were determined by the CNS 2000. Available phosphorus was determined by The Bray II method. The exchangeable bases $(\mathrm{Ca}, \mathrm{Mg}, \mathrm{K}$ and $\mathrm{Na}$ ) and $\mathrm{CEC}$ were determined by leaching method where ten grams of air dried soil were placed into leaching tube and leached with $100 \mathrm{~mL}$ of $1 \mathrm{M}$ $\mathrm{NH}_{4} \mathrm{OAc}$ at $\mathrm{pH} 7.0$ by adjusting the interval of drift about 8 to 10 seconds. The leachate was collected and its cation $(\mathrm{K}, \mathrm{Ca}, \mathrm{Mg}$ and $\mathrm{Na})$ determined by Atomic Absorption Spectrometer (AAS). The leached soil sample was washed with $100 \mathrm{~mL}$ of $95 \%$ ethanol to remove excess ammonium ions and then leached with $100 \mathrm{~mL} 0.05 \mathrm{M} \mathrm{K}_{2} \mathrm{SO}_{4}$ and the leachate was collected for CEC determination using auto-analyzer. Exchangeable aluminum ( $\mathrm{Al})$ and hydrogen $(\mathrm{H})$ were determined using the filtrate obtained from $\mathrm{pH}-\mathrm{KCl}$ suspension pipettes $10 \mathrm{~mL}$ of the filtrate into a $100 \mathrm{~mL}$ Erlenmeyer flask and added with 3 drops of the Phenolphthalein indicator. The volume of $0.01 \mathrm{M}$ $\mathrm{NaOH}$ solution used to titrate until first permanent pink endpoint was recorded as (x). After adding $5 \mathrm{~mL}$ of $4 \%$ $\mathrm{NaF}$, it was titrate with $0.01 \mathrm{M} \mathrm{HCl}$ and the volume of $\mathrm{HCl}$ solution used was recorded.

Data analyses: The data on physico-chemical properties for three soil series were analyzed using oneway ANOVA followed by Tukey's HSD test. The independent student $t$-test was used to examine any significant difference in soil properties between plantation and secondary forests and/or soil fertility status using SFI and SEF values. A standard multiple regression analysis was used to determine the significant difference among soil properties. All of the data were analyzed using Statistical Packages for Social Packages for Social Science (SPSS) software ver. 17.

Soil index was used to determine the factor that affect the soil fertility by integrating the soil physicochemical properties. For estimating soil fertility and site quality, two indices were used: 1) Soil Fertility Index 
(SFI) (Moran et al., 2000); and 2) Soil Evaluation Factor (SEF) (Lu et al. 2002).

$\mathrm{SFI}=\mathrm{pH}+$ organic matter $(\%$, dry soil basis $)+$ available $\mathrm{P}\left(\mathrm{mg} \mathrm{kg}^{-1}\right.$, dry soil) + exchangeable $\mathrm{Ca}$ $\left(\mathrm{cmol}_{\mathrm{c}} \mathrm{kg}^{-1}\right.$ dry soil $)+$ exchangeable $\mathrm{Mg}\left(\mathrm{cmol}_{\mathrm{c}} \mathrm{kg}^{-1}\right.$ dry soil) + exchangeable $\mathrm{K}\left(\mathrm{cmol}_{\mathrm{c}} \mathrm{kg}^{-1}\right.$ dry soil) exchangeable $\mathrm{Al}\left(\mathrm{cmol}_{\mathrm{c}} \mathrm{kg}^{-1}\right.$ dry soil).

$\mathrm{SEF}=\left[\right.$ exchangeable $\mathrm{Ca}\left(\mathrm{cmol}_{\mathrm{c}} \mathrm{kg}^{-1}\right.$ dry soil $)+$ exchangeable $\mathrm{Mg}\left(\mathrm{cmol}_{\mathrm{c}} \mathrm{kg}^{-1}\right.$ dry soil) + exchangeable $\mathrm{K}\left(\mathrm{cmol}_{\mathrm{c}} \mathrm{kg}^{-1}\right.$ dry soil)-log (1+ exchangeable $\mathrm{Ca}\left(\mathrm{cmol}_{\mathrm{c}}\right.$ $\mathrm{kg}^{-1}$ dry soil)] x organic matter $(\%$, dry soil basis $)+5$.

\section{RESULTS AND DISCUSSION}

\section{Characteristics of soils under $K$. ivorensis} plantation: The soil properties of Rengam, Durian and Padang Besar series are presented in Table 1. There were significantly differences in almost all of physico-chemical properties of soils between soil series, particularly for surface soil. The results also showed that the soils under $K$. ivorensis stand were moderately acidic to slightly acidic for subsurface soil ( $\mathrm{pH}$ ranged from 4.97-5.85), whereas the surface soils were moderately acidic ( $\mathrm{pH}$ ranged from 5.07-5.42). The $\mathrm{pH}$ of Padang Besar series was significantly higher as compared with that of Durian and Rengam series. For Padang Besar soil series, the value was 5.42 for surface soil and 5.85 for subsurface. The lowest $\mathrm{pH}$ for Rengam was 5.07 (surface) and 4.97 (subsurface).

Total carbon content in surface soil was significantly different among soil series whereas no significant difference was found subsurface (Table 1). In Rengam series, total carbon in surface soil had the highest value of $16.11 \mathrm{~g} \mathrm{~kg}^{-1}$, while that for Durian and Padang Besar it was $13.14 \mathrm{~g} \mathrm{~kg}^{-1}$ and $12.24 \mathrm{~g} \mathrm{~kg}^{-1}$, respectively. Total $\mathrm{N}$ in surface soil was significantly different between soil series. The highest value was $1.29 \mathrm{~g} \mathrm{~kg}^{-1}, 0.91 \mathrm{~g} \mathrm{~kg}^{-1}$ and $0.72 \mathrm{~g} \mathrm{~kg}^{-1}$, respectively for Padang Besar, Durian and Rengam. In contrast, total N in subsurface soil was not significantly different among soil series, with respective value was in Padang Besar, Rengam and Durian of $1.08,1.17$ and $1.22 \mathrm{~g} \mathrm{~kg}^{-1}$. Meanwhile, there was a significant difference in the $\mathrm{C} / \mathrm{N}$ ratio $(\mathrm{P}<0.05)$ for surface soil of which Rengam series showed the highest value of 32.24; the highest value for Padang Besar was 16.35 and for Durian series 18.22. This indicates that the content of organic matter for the surface soil of Rengam was higher than that of Padang Besar and Durian series. This explains the decomposition rate of organic matter in Rengam soil was lower than that of Padang Besar or Durian soil. Organic matter affects the CEC of soils. Likewise, the
CEC is affected the type of clay (or amount of clay) present in the soils. Therefore, soils with high organic matter or with high clay content have higher CEC than soils with low organic matter or sandy soils (Hardjowigeno, 2007). This is supported by the study of Abdu et al. (2008) who reported that surface soil in natural forest at Bukit Kinta Forest Reserve which have higher organic matter and clay content than that in planted forest has higher CEC compared with that of planted forest.

The availability of soil inorganic phosphate is determined by soil $\mathrm{pH}$. The amount of $\mathrm{Fe}, \mathrm{Al}, \mathrm{Mn}$, the availability of $\mathrm{Ca}$ and the amount and rate of decomposition of organic matter and microorganism activity soil $\mathrm{pH}$. The available phosphorus in surface soil and subsurface soil was similar. Available $\mathrm{P}$ in surface soil ranged from 1.85 to $2.13 \mathrm{mg} \mathrm{kg}^{-1}$, while in subsurface soil it ranged from 1.96 to $2.06 \mathrm{mg} \mathrm{kg}^{-1}$. The results showed that there were significant differences of available $\mathrm{P}$ between soil series $(\mathrm{P}<0.05)$. The available $\mathrm{P}$ in Rengam for both surface and subsurface soils was higher (2.13 and $2.05 \mathrm{mg} \mathrm{kg}^{-1}$, respectively) as compared to that of Durian (2.09 and $2.06 \mathrm{mg} \mathrm{kg}^{-1}$, respectively) and Padang Besar series (1.85 and 1.96 $\mathrm{mg} \mathrm{kg}{ }^{-1}$, respectively). According to Lal (1997), in tropical and subtropical regions, one of the limiting factors of forest productivity is low phosphorus availability. But every tree species demands phosphorus differently and some have better capacity to extract phosphorus in fixed form from soils.

In all soil series, the exchangeable bases in the surface and subsurface soils were low in comparison to the exchangeable $\mathrm{Al}$, resulting in high level of $\mathrm{Al}$ saturation (Arifin et al., 2008; Abdu et al., 2008). The high level of Al saturation could be the reason of low available nutrients in particular $\mathrm{P}$, because the nutrients was fixed by $\mathrm{Al}$, so it could not be used by plants for its growth (Hardjowigeno, 2007). Lu et al. (2002) reported that physical structure was related with nutrient accumulation, while chemical properties $(\mathrm{Ca}, \mathrm{Mg}, \mathrm{K}$ and $\mathrm{OM}$ ) have significant effects on biomass accumulation. Increasing these nutrients induces fast vegetation growth rate, but increasing $\mathrm{Al}$ content tends to restrict vegetation growth ( $\mathrm{Lu}$ et al., 2002). The cation exchange capacity (CEC) and effective cation exchange capacity (ECEC) of the Rengam series for surface and subsurface soils were significantly higher than those in the Durian and Padang Besar soil series. These results indicate that the soil of Rengam series has a greater ability to absorb cations compared with that of Durian and Rengam soil series. 
Am. J. Applied Sci., 8 (5): 472-480, 2011

Table 1: Comparison of physico-chemical properties between soil series under K. ivorensis plantation

\begin{tabular}{|c|c|c|c|c|c|c|}
\hline \multirow{2}{*}{$\begin{array}{l}\text { Soil properties } \\
\text { Surface soil }(0-10 \mathrm{~cm})\end{array}$} & \multicolumn{6}{|l|}{ Soil series } \\
\hline & \multicolumn{2}{|c|}{ Padang Besar $(\mathrm{n}=18)$} & \multicolumn{2}{|l|}{ Durian $(n=18)$} & \multicolumn{2}{|l|}{ Rengam $(n=18)$} \\
\hline $\mathrm{pH}\left(\mathrm{H}_{2} \mathrm{O}\right)$ & $5.42(0.1)$ & $\mathrm{a}$ & $5.22(0.1)$ & $\mathrm{b}$ & $5.07(0.1)$ & $\mathrm{b}$ \\
\hline $\mathrm{pH}(\mathrm{KCl})$ & $4.30(0.1)$ & a & $4.26(0.1)$ & a & $3.89(0.1)$ & $\mathrm{b}$ \\
\hline Total $\mathrm{C}\left(\mathrm{g} \mathrm{kg}^{-1}\right)$ & $12.24(0.9)$ & $\mathrm{b}$ & $13.14(1.1)$ & $\mathrm{b}$ & $16.11(1.2)$ & $\mathrm{a}$ \\
\hline Total N $\left(\mathrm{g} \mathrm{kg}^{-1}\right)$ & $1.29(0.43)$ & $\mathrm{a}$ & $0.91(0.08)$ & $\mathrm{b}$ & $0.72(0.1)$ & $\mathrm{b}$ \\
\hline $\mathrm{C} / \mathrm{N}$ ratio & $16.35(3.25)$ & $\mathrm{c}$ & $18.22(4.55)$ & $\mathrm{b}$ & $32.24(7.03)$ & a \\
\hline $\mathrm{CEC}\left(\mathrm{cmol}_{\mathrm{c}} \mathrm{kg}^{-1}\right)$ & $5.89(0.2)$ & $\mathrm{c}$ & $6.78(0.3)$ & $\mathrm{b}$ & $10.93(0.4)$ & $\mathrm{a}$ \\
\hline Exchangeable $\mathrm{Ca}\left(\mathrm{cmol}_{\mathrm{c}} \mathrm{kg}^{-1}\right)$ & $0.36(0.03)$ & $\mathrm{b}$ & $0.62(0.07)$ & $\mathrm{a}$ & $0.59(0.05)$ & $\mathrm{a}$ \\
\hline Exchangeable $\mathrm{Mg}\left(\mathrm{cmol}_{\mathrm{c}} \mathrm{kg}^{-1}\right)$ & $0.16(0.01)$ & $\mathrm{b}$ & $0.30(0.02)$ & $\mathrm{a}$ & $0.20(0.01)$ & $\mathrm{b}$ \\
\hline Exchangeable $\mathrm{K}\left(\mathrm{cmol}_{\mathrm{c}} \mathrm{kg}^{-1}\right)$ & $0.17(0.01)$ & ns & $0.20(0.01)$ & ns & $0.20(0.02)$ & ns \\
\hline Exchangeable $\mathrm{Na}\left(\mathrm{cmol}_{\mathrm{c}} \mathrm{kg}^{-1}\right)$ & $0.03(0.003)$ & $\mathrm{b}$ & $0.05(0.003)$ & $\mathrm{a}$ & $0.05(0.004)$ & $\mathrm{a}$ \\
\hline Exchangeable $\mathrm{Al}\left(\mathrm{cmol}_{\mathrm{c}} \mathrm{kg}^{-1}\right)$ & $3.51(0.34)$ & a & $2.72(0.17)$ & $\mathrm{b}$ & $3.45(0.31)$ & a \\
\hline $\operatorname{ECEC~}\left(\mathrm{cmol}_{\mathrm{c}} \mathrm{kg}^{-1}\right)$ & $4.22(0.34)$ & $\mathrm{a}$ & $3.88(0.21)$ & $\mathrm{b}$ & $4.48(0.31)$ & $\mathrm{a}$ \\
\hline Al saturation (\%) & $81.83(1.79)$ & $\mathrm{a}$ & $69.89(2.13)$ & $\mathrm{b}$ & $74.88(3.57)$ & $a b$ \\
\hline Available $\mathrm{P}\left(\mathrm{mg} \mathrm{P} \mathrm{kg}^{-1}\right)$ & $1.85(0.09)$ & $\mathrm{b}$ & $2.09(0.08)$ & $\mathrm{a}$ & $2.13(0.11)$ & $\mathrm{a}$ \\
\hline Clay $(\%)$ & $16.39(0.85)$ & $\mathrm{b}$ & $18.99(3.19)$ & $\mathrm{b}$ & $36.74(1.22)$ & a \\
\hline Silt (\%) & $17.65(0.69)$ & a & $15.26(0.26)$ & $\mathrm{b}$ & $18.68(0.62)$ & a \\
\hline Sand $(\%)$ & $65.96(1.30)$ & $\mathrm{a}$ & $65.75(2.39)$ & $\mathrm{a}$ & $44.58(0.89)$ & $\mathrm{b}$ \\
\hline Bulk density $\left(\mathrm{g} \mathrm{cm}^{-3}\right)$ & $1.31(0.32)$ & ns & $1.29(0.28)$ & ns & $1.19(0.21)$ & ns \\
\hline Subsurface soil $(20-30 \mathrm{~cm})$ & Padang Besar & & Durian $(n=18)$ & & Rengam $(n=18)$ & \\
\hline $\mathrm{pH}\left(\mathrm{H}_{2} \mathrm{O}\right)$ & $5.85(0.12)$ & $\mathrm{a}$ & $5.21(0.15)$ & $\mathrm{b}$ & $4.97(0.08)$ & $\mathrm{b}$ \\
\hline $\mathrm{pH}(\mathrm{KCl})$ & $4.38(0.17)$ & $\mathrm{a}$ & $4.35(0.17)$ & a & $4.00(0.19)$ & $\mathrm{b}$ \\
\hline Total C $\left(\mathrm{g} \mathrm{kg}^{-1}\right)$ & $7.65(0.41)$ & ns & $8.67(1.63)$ & ns & $9.1(0.72)$ & ns \\
\hline Total $\mathrm{N}\left(\mathrm{g} \mathrm{kg}^{-1}\right)$ & $1.08(0.10)$ & ns & $1.22(0.08)$ & ns & $1.17(0.06)$ & ns \\
\hline $\mathrm{C} / \mathrm{N}$ ratio & $7.52(0.98)$ & ns & $7.50(1.65)$ & ns & $8.08(1.15)$ & ns \\
\hline $\mathrm{CEC}\left(\mathrm{cmol}_{\mathrm{c}} \mathrm{kg}^{-1}\right)$ & $4.98(0.02)$ & $\mathrm{c}$ & $7.17(0.43)$ & $\mathrm{b}$ & $9.17(0.66)$ & $\mathrm{a}$ \\
\hline Exchangeable $\mathrm{Ca}\left(\mathrm{cmol}_{\mathrm{c}} \mathrm{kg}^{-1}\right)$ & $0.25(0.12)$ & $\mathrm{b}$ & $0.33(0.02)$ & $\mathrm{a}$ & $0.30(0.02)$ & $a b$ \\
\hline Exchangeable $\mathrm{Mg}\left(\mathrm{cmol}_{\mathrm{c}} \mathrm{kg}^{-1}\right)$ & $0.17(0.01)$ & ns & $0.22(0.02)$ & ns & $0.19(0.01)$ & ns \\
\hline Exchangeable $\mathrm{K}\left(\mathrm{cmol}_{\mathrm{c}} \mathrm{kg}^{-1}\right)$ & $0.16(0.01)$ & ns & $0.14(0.001)$ & ns & $0.13(0.01)$ & ns \\
\hline Exchangeable $\mathrm{Na}\left(\mathrm{cmol}_{\mathrm{c}} \mathrm{kg}^{-1}\right)$ & $0.05(0.001)$ & ns & $0.04(0.001)$ & ns & $0.06(0.004)$ & ns \\
\hline Exchangeable $\mathrm{Al}\left(\mathrm{cmol}_{\mathrm{c}} \mathrm{kg}^{-1}\right)$ & $3.12(0.15)$ & $\mathrm{b}$ & $2.72(0.11)$ & $\mathrm{b}$ & $3.62(0.53)$ & $\mathrm{a}$ \\
\hline $\operatorname{ECEC~}\left(\mathrm{cmol}_{\mathrm{c}} \mathrm{kg}^{-1}\right)$ & $3.74(0.16)$ & $\mathrm{b}$ & $3.45(0.11)$ & $\mathrm{b}$ & $4.30(0.53)$ & $\mathrm{a}$ \\
\hline $\mathrm{Al}$ saturation $(\%)$ & $83.22(1.13)$ & ns & $78.90(1.16)$ & $\mathrm{ns}$ & $82.86(2.45)$ & ns \\
\hline Available $\mathrm{P}\left(\mathrm{mg} \mathrm{P} \mathrm{kg}^{-1}\right)$ & $1.96(0.13)$ & $\mathrm{b}$ & $2.06(0.13)$ & $\mathrm{a}$ & $2.05(0.10)$ & $\mathrm{a}$ \\
\hline Clay $(\%)$ & $23.05(0.75)$ & $\mathrm{b}$ & $24.81(0.70)$ & $\mathrm{b}$ & $46.53(0.94)$ & a \\
\hline Silt $(\%)$ & $16.92(0.98)$ & $\mathrm{a}$ & $14.08(0.37)$ & $\mathrm{b}$ & $16.72(0.37)$ & $\mathrm{a}$ \\
\hline Sand $(\%)$ & $60.03(1.13)$ & $\mathrm{a}$ & $61.11(7.17)$ & $\mathrm{a}$ & $36.75(0.86)$ & $\mathrm{b}$ \\
\hline Bulk density $\left(\mathrm{g} \mathrm{cm}^{-3}\right)$ & $1.39(0.35)$ & ns & $1.34(0.27)$ & ns & $1.32(0.18)$ & ns \\
\hline
\end{tabular}

Note: Parentheses indicate standard error; different letters in the same row indicate significant differences among sites at 5\% using Tukey's HSD test; ns, no significant difference; ECEC, Exch. $\mathrm{Ca}+\mathrm{Mg}+\mathrm{K}+\mathrm{Na}+\mathrm{Al}$; Al saturation, (Exch. Al/ECEC) $\times 100$

There were significant differences in the particlesize distribution between soil series. In the case of sand, Padang Besar and Durian soils have higher value compared with Rengam soil for both surface and subsurface soils. For clay content, the highest value in Rengam soil was $36.74 \%$ for surface soil and $46.53 \%$ for subsurface soil. The lowest value of clay content in Padang Besar soil was $16.39 \%$ in surface soil and $23.05 \%$ in subsurface soil. In the case of silt, the highest value was recorded in Rengam soil with value of $18.68 \%$ in surface soil and $16.72 \%$ in subsurface soil. The lowest value of silt content was in Durian soil with value of $15.26 \%$ in surface soil and $14.08 \%$ in subsurface soil. According to Lu et al. (2002), physical structure is related to nutrient content retention in the soil layers. Higher clay content associated with lower coarse sand content can hold more nutrients in the soil. Conversely, low clay content associated with high coarse sand content results in low nutrient retention in the soil. Multiple regression analysis showed that clay content and total carbon in Rengam series were highly and positively correlated with $\mathrm{CEC}$ at $\mathrm{P}<0.01$ (data not shown). These results indicate that negative charge derived from clay and organic matter play an important role in retaining soil cation nutrients.

Comparison of soil properties between planted and secondary forests: Table 2 shows the influence of planting of $K$. ivorensis (planted forest) on its soil properties conditions compared with the soil properties at adjacent secondary forests. The soil properties of planted forest are mean of soil properties within three soil series. 
Am. J. Applied Sci., 8 (5): 472-480, 2011

Table 2: Comparison of physico-chemical properties in surface and subsurface soils between planted and secondary forests

\begin{tabular}{|c|c|c|c|c|c|c|}
\hline \multirow[b]{3}{*}{ Soil properties } & \multicolumn{6}{|l|}{ Sites } \\
\hline & \multicolumn{2}{|l|}{ Surface soil } & \multirow[b]{2}{*}{ t-test } & \multicolumn{2}{|l|}{ Subsurface soil } & \multirow[b]{2}{*}{ t-test } \\
\hline & Planted forest & Secondary forest & & Planted forest & Secondary forest & \\
\hline $\mathrm{pH}\left(\mathrm{H}_{2} \mathrm{O}\right)$ & $5.23(0.11)$ & $4.43(0.13)$ & ns & $5.34(0.12)$ & $5.72(0.11)$ & ns \\
\hline $\mathrm{pH}(\mathrm{KCl})$ & $4.15(0.10)$ & $4.06(0.09)$ & ns & $4.24(0.11)$ & $3.99(0.08)$ & ns \\
\hline Total C $\left(\mathrm{g} \mathrm{kg}^{-1}\right)$ & $13.78(0.92)$ & $16.03(1.17)$ & $\mathrm{ns}$ & $8.47(0.98)$ & $9.19(0.98)$ & ns \\
\hline Total $\mathrm{N}\left(\mathrm{g} \mathrm{kg}^{-1}\right)$ & $0.97(0.07)$ & $0.58(0.07)$ & ns & $1.36(0.12)$ & $0.80(0.06)$ & ns \\
\hline $\mathrm{C} / \mathrm{N}$ ratio & $22.27(3.22)$ & $49.38(5.36)$ & * & $7.69(1.13)$ & $15.81(1.56)$ & $*$ \\
\hline $\mathrm{CEC}\left(\mathrm{cmol}_{\mathrm{c}} \mathrm{kg}^{-1}\right)$ & $7.86(0.23)$ & $5.81(0.18)$ & ns & $7.10(0.21)$ & $5.90(0.27)$ & ns \\
\hline Exchangeable $\mathrm{Ca}\left(\mathrm{cmol}_{\mathrm{c}} \mathrm{kg}^{-1}\right)$ & $0.51(0.09)$ & $0.50(0.10)$ & ns & $0.29(0.08)$ & $0.25(0.07)$ & ns \\
\hline Exchangeable $\mathrm{Mg}\left(\mathrm{cmol}_{\mathrm{c}} \mathrm{kg}^{-1}\right)$ & $0.21(0.02)$ & $0.19(0.03)$ & ns & $0.19(0.03)$ & $0.14(0.02)$ & $\mathrm{ns}$ \\
\hline Exchangeable $\mathrm{K}\left(\mathrm{cmol}_{\mathrm{c}} \mathrm{kg}^{-1}\right)$ & $0.18(0.01)$ & $0.17(0.01)$ & $\mathrm{ns}$ & $0.14(0.01)$ & $0.21(0.02)$ & $*$ \\
\hline Exchangeable $\mathrm{Na}\left(\mathrm{cmol}_{\mathrm{c}} \mathrm{kg}^{-1}\right)$ & $0.04(0.003)$ & $0.05(0.004)$ & $\mathrm{ns}$ & $0.04(0.002)$ & $0.07(0.003)$ & $*$ \\
\hline Exchangeable $\mathrm{Al}\left(\mathrm{cmol}_{\mathrm{c}} \mathrm{kg}^{-1}\right)$ & $3.22(0.24)$ & $3.42(0.35)$ & $\mathrm{ns}$ & $3.15(0.21)$ & $4.06(0.25)$ & ns \\
\hline $\operatorname{ECEC~}\left(\mathrm{cmol}_{\mathrm{c}} \mathrm{kg}^{-1}\right)$ & $4.19(0.15)$ & $4.35(0.15)$ & ns & $3.83(0.18)$ & $4.64(0.19)$ & ns \\
\hline Al saturation (\%) & $75.53(1.98)$ & $77.50(2.18)$ & ns & $81.65(2.54)$ & $87.11(3.25)$ & ns \\
\hline Available P (mg P kg $\left.{ }^{-1}\right)$ & $2.02(0.11)$ & $1.96(0.35)$ & $*$ & $2.05(0.19)$ & $2.00(0.16)$ & ns \\
\hline Clay $(\%)$ & $24.04(0.87)$ & $12.47(0.54)$ & $*$ & $31.45(0.67)$ & $16.40(0.39)$ & $*$ \\
\hline Silt (\%) & $17.16(0.87)$ & $19.11(0.65)$ & ns & $15.90(0.49)$ & $19.33(0.78)$ & ns \\
\hline Sand (\%) & $58.73(2.39)$ & $68.30(3.24)$ & $\mathrm{ns}$ & $52.61(2.87)$ & $64.20(4.58)$ & $\mathrm{ns}$ \\
\hline
\end{tabular}

Note: Parentheses indicate standard error; significant difference between sites at 5\% using Tukey's HSD test; ns, no significant difference; *, significant difference; ECEC, Exch. $\mathrm{Ca}+\mathrm{Mg}+\mathrm{K}+\mathrm{Na}+\mathrm{Al}$; Al saturation, $($ Exch. Al/ECEC) $\times 100$

The $\mathrm{pH}$ value in surface soil of planted forest is higher than in secondary forest, while $\mathrm{pH}$ value for subsurface soil in secondary forest was higher than that in planted forest. The soils in planted forest were moderately acidic, with $\mathrm{pH}\left(\mathrm{H}_{2} \mathrm{O}\right)$ of less than 5.5. The soil in secondary forest for surface soil was moderately acidic, while in subsurface soil was slightly acidic, with $\mathrm{pH}$ $\left(\mathrm{H}_{2} \mathrm{O}\right)$ more than 5.5 (Amacher et al., 2007). The results indicate that planting of $K$. ivorensis seems to have the potential in shifted the $\mathrm{pH}$ value into higher value than as was found in secondary forests.

The results also exhibited that for the surface soils, there were no significant differences between planted and secondary forests in almost all of the soil properties except $\mathrm{C} / \mathrm{N}$ ratio, available $\mathrm{P}$ and content clay content. For the subsurface soil there was significant difference for $\mathrm{C} / \mathrm{N}$ ratio, exchangeable $\mathrm{K}$, exchangeable $\mathrm{Na}$ and clay content. The $\mathrm{C} / \mathrm{N}$ ratio of soils in planted forest for both surface and subsurface soils was lower than that in secondary forests (Table 2). This indicates that the decomposition rate of organic matter in planted forest is faster than that in secondary forest. The rate of decomposition can be seen from the total value of $\mathrm{N}$, if the total $\mathrm{N}$ small, the rate of decomposition will be low, resulting in inhibition of plant growth.

The available $\mathrm{P}$ in the surface soils of planted forest $\left(2.02 \mathrm{mg} \mathrm{kg}^{-1}\right)$ for surface soil was higher and significantly different compared with that of the secondary forests $\left(1.96 \mathrm{mg} \mathrm{kg}^{-1}\right)$, while for subsurface soil, there was no significant difference between planted $\left(2.05 \mathrm{mg} \mathrm{kg}^{-1}\right)$ and secondary forests $(2.0 \mathrm{mg}$ $\mathrm{kg}^{-1}$ ). Meanwhile, the exchangeable $\mathrm{K}$ and $\mathrm{Na}$ in the subsurface soil were significantly different between planted and secondary forests, but there was no significant difference was found for surface soil. In addition, no significant difference was observed for exchangeable $\mathrm{Ca}$ and $\mathrm{Mg}$ between planted and secondary forests for both the surface and subsurface soils. Overall, the exchangeable bases of soils in the planted forest were higher than that in the secondary forest. This is indicates that $K$. ivorensis was planted at 5 years old did not reduce nutrients in the soil. These results differ from studies by Abdu et al. (2008) who worked on 11-year-old dipterocarp species (Shorea Pauciflora and S. Macroptera) in Perak, Malaysia. In this study, it was found soils in the planted contained less $\mathrm{Ca}, \mathrm{Mg}$ and $\mathrm{K}$ and available $\mathrm{P}$ compared with the adjacent natural forest. This tendency shows that the vegetations and stand age have a very important role in changing soil conditions.

The CEC of surface and subsurface soils in the planted forest was higher than that in secondary forests. This indicates that the planted forest is more fertile than that of the secondary forest. The clay content of soils in the planted forest is higher than that of the secondary forest. It means that soils in the planted forest can hold more nutrients. Zaidey et al. (2010) reported that for sandy soils the negative charges from clay minerals play important roles in retaining and releasing soil nutrients. 
Am. J. Applied Sci., 8 (5): 472-480, 2011

Table 3: Comparison of soil fertility between soil series under K. ivorensis plantation using SFI and SEF indices

\begin{tabular}{|c|c|c|c|c|}
\hline \multirow[b]{2}{*}{ Soil series } & \multicolumn{2}{|l|}{ SFI } & \multicolumn{2}{|l|}{ SEF } \\
\hline & Surface & Subsurface & Surface & Subsurface \\
\hline Padang Besar & $25.27(1.67)^{b}$ & $18.46(0.70)^{\mathrm{ns}}$ & $5.94(1.12)^{b}$ & $4.50(0.58)^{\mathrm{ns}}$ \\
\hline Durian & $28.35(1.83)^{a b}$ & $20.29(2.70)^{n s}$ & $16.96(2.29)^{\mathrm{a}}$ & $6.43(0.65)^{\mathrm{ns}}$ \\
\hline Rengam & $32.51(2.38)^{\mathrm{a}}$ & $19.70(1.73)^{\mathrm{ns}}$ & $16.40(3.48)^{\mathrm{a}}$ & $4.87(0.92)^{\mathrm{ns}}$ \\
\hline
\end{tabular}

Note: Different superscripts letter (s) in the same column indicate significant difference between soil series at the 5\%, ns, no significant difference; SFI, soil fertility index; SEF, soil evaluation factor

Table 4: Comparison of soil fertility between planted and secondary forests under K. ivorensis plantation using SFI and SEF indices

\begin{tabular}{|c|c|c|c|c|}
\hline \multirow[b]{2}{*}{ Sites } & \multicolumn{2}{|l|}{ SFI } & \multicolumn{2}{|l|}{ SEF } \\
\hline & Surface & Subsurface & Surface & Subsurface \\
\hline Planted area & $28.71(1.22)^{\mathrm{ns}}$ & $19.48(1.05)^{\mathrm{ns}}$ & $13.10(1.68)^{\mathrm{ns}}$ & $5.27(0.72)^{\mathrm{ns}}$ \\
\hline Secondary forest & $32.50(2.35)^{\mathrm{ns}}$ & $20.02(3.54)^{\mathrm{ns}}$ & $12.84(3.11)^{\mathrm{ns}}$ & $4.26(1.74)^{\text {ns }}$ \\
\hline
\end{tabular}

In order to achieve sustainable production with minimal soil degradation, land-use planning and soil management must be taken into account because planting trees could reduce soil erosion and increase soil nutrients through organic matter accumulation (Lavelle, 1987). In this study, it seems that planting fast growing $K$. ivorensis have increased organic matter and plant nutrients as compared to secondary forest. This result indicates that the potential of fast growing species for rehabilitating degraded forestland by means of improving site productivity and soil fertility. Similarly, Evans (1999) and Sawyer (1993) stated that forest plantation have great potential for restoring degraded sites in the tropics. Bowyer (2005) reported the negative impacts of forestation can be avoided by proper matching of species to site. Therefore, for degraded secondary forest or forestland such as in the present study, the selection of species and site suitability need to be taken into consideration, if the government and private agencies intend to establish future forest plantation towards increasing site productivity.

Assessing soil fertility status using SFI and SEF: The complexity of soil properties make it difficult to find an appropriate method to evaluate soil condition in the humid tropical (Lu, et al., 2002). Therefore, for estimating soil fertility and site quality, Moran et al. (2000) and Lu et al. (2002) developed methods called Soil Fertility Index (SFI) and Soil Evaluation Factor (SEF), respectively. The methods were used to estimate soil fertility and site productivity under different succession stage of secondary forest in the tropical Amazon forest. Both SFI and SEF are applicable for estimating soil fertility and site quality under dipterocarp plantation in rehabilitated degraded forestland in Perak, Malaysia (Abdu et al., 2008; Zaidey et al., 2010). In the current study, we used both SFI and SEF for estimating soil fertility and site quality of three soil series under five-year-old $K$. ivorensis (Table 3). The results show that there was no significant difference of SFI and SEF values among soil series. The highest SFI was for the surface soils of Rengam soil, followed by Durian and Padang Besar soils. The value of SEF showed that the Durian soil series exhibited the highest, followed by Rengam and Padang Besar.

In addition, we also used SFI dan SEF indices for estimating soil fertility and site quality in adjacent secondary forest in order to compare the values obtained with those of the planted forest. Although the value of SFI at surface and subsurface soils in secondary forest was higher than planted forest, but no significant difference was found (Table 4). Similarly, there were no significant differences in SEF of the surface and subsurface soils for planted and secondary forests.

\section{CONCLUSION}

This study showed that Rengam soil is more fertile as compared with Durian and Padang Besar soils. The Rengam soil contained higher organic matter and clay, resulting in higher value of CEC than the other two soils. It seems that the soil under 5-year-old $K$. ivorensis stand did not have much different from that of the secondary forest. The SFI revealed that soil fertility status under Padang Besar was significantly higher than other soil series, whereas no significant difference was observed for SEF. The results also showed that, no significant difference was observed between planted and secondary forest by using SFI and SEF. These results suggest that plantation of fast growing exotic 
species such as K. ivorensis could increase the fertility of soils. The SFI and SEF indices are suitable as an index for estimating both soil fertility and site quality of different soil series under $K$. ivorensis plantation. However, further studies on soil conditions under $K$. ivorensis plantation after more than ten years need to be identified in order to clarify the role of forest plantation in terms of site productivity and carbon sequestration.

\section{ACKNOWLEDGMENT}

This study was funded by Forest Research Institute Malaysia (FRIM) and by the Fundamental Research Grant Scheme (FRGS) received from the Ministry of Higher Education of Malaysia (MOHE) through Universiti Putra Malaysia, Malaysia. In kind support from FRIM and Faculty of Forestry, UPM staff that helps in fieldwork during forest survey and destructive sampling is highly acknowledged. We are grateful to Ms. Zarina Abdul Rahman, Mr. Arwel, Mr. Hafizuddin, Ms. Norisah and Ms. Debora for their field and laboratory assistance. We would like to thank two anonymous reviewers for their valuable and helpful suggestion and comments.

\section{REFERENCES}

Amacher, M.C., K.P. O'Neil and C.H. Perry, 2007. Soil vital signs: A new Soil Quality Index (SQI) for assessing forest soil health. USDA Forest Service Res. Pap. RMRS-RP-65WWW. http://www.fs.fed.us/rm/pubs/rmrs_rp065.pdf

Appanah, S. and G. Weinland, 1993. Planting Quality Timber Trees in Peninsular Malaysia: A Review. 1st Edn., Forest Research Institute Malaysia, Malaysia, ISBN: 9839592181, pp: 221.

Abdu, S., S. Tanaka, S. Jusop, N.M. Majid and Z. Ibrahim et al., 2008. Assessment on soil fertility status and growth performance of planted dipterocarp species in Perak, Peninsisular Malaysia, Scientific Commons. http://en.scientificcommons.org/38872233

Bowyer, D.J., 2005. Fast-Growth Tree Plantations for Wood Production Environmental Threat or a Means of "Saving" Natural Forests. Dovetail Partners, Inc. http://www.dovetailinc.org/reportsview/2005/sustai nable-forestry/pdr-jim-bowyerp/fast-growth-treeplantations-wood-production- $\% \mathrm{E} 2 \% 80 \% 93$

Evans, J., 1999. Planted forests of the wet and dry tropics: Their variety, nature, and significance. New Forests, 17: 25-36. DOI: 10.1023/A:1006572826263
FAO, 2005. Global Forest Resources Assessment. 2005: Progress towards Sustainable Forest Management. Food and Agriculture Organization . http://www.eia.doe.gov/oiaf/1605/archive/gg04rpt/ global forest.html.

Hamzah, M.Z., A. Arifin, A.K.M. Zaidey, A.N. Azirim and I. Zahari et al., 2009. Characterizing soil nutrient status and growth performance of planted dipterocap and non-dipterocarp species on degraded forest land in Peninsular Malaysia. J. Applied Sci., 9: 4215-4223. DOI: $10.3923 /$ jas. 2009.4215 .4223

Hardjowigeno, S., 2007. Ilmu Tanah. 1st Edn., Jakarta, MSP., ISBN-10: 9794550183

Jeyanny, V., A.G.A. Rasip, K.W. Rasidah and Y.A. Zuhaidi, 2009. Effects of macronutrient deficiencies on the growth and vigour of Khaya ivorensis seedlings. J. Trop. Sci., 21: 73-80.

Jordan, C.F., 1989. An Amazonian Rain Forest: The Structure and Function of a Nutrient Stressed Ecosystem and the Impact of Slash-and-Burn Agriculture. 1st Edn., UNESCO, USA., ISBN-10: 9231026291, pp: 176.

Lal, R., 1997. Soils of the tropics and their management for plantation forestry. In: Management of soil, nutrients and water in tropical plantation forests, Nambiar, E.K.S. and A.G. Brown, (Eds.)., ACIAR Monograph No. 43, Canberra, pp: 97-123. http://www.cabdirect.org/abstracts/19980603521.ht $\mathrm{ml}$

Lavelle, P., 1987. Biological processes and productivity of soils in the humid tropics. The Geophysiology of Amazonia: Vegetation and Climate Interactions, Robert ED (Ed.)., Wiley: New York, pp: 175-222.

Lu, D., E. Moran and P. Mausel, 2002. Linking Amazonian secondary succession forest growth to soil properties. Land Deg. Dev. 13: 331-343. DOI: $10.1002 / \mathrm{ldr} .516$

Lugo, A.E., 1997. The apparent paradox of reestablishing species richness on degraded lands with tree monocultures. For. Ecol. Manage., 99: 9-19. DOI: 10.1016/S0378-1127(97)00191-6

Montagnini, F., B. Eibl, L. Grance, D. Maiocco and D. Nozzi, 1997. Enrichment planting in overexploited subtropical forests of the Paranaense region of Misiones, Argentina. For. Ecol. Manage., 99: 237-246. DOI: 10.1016/S0378-1127(97)00209-0

Moran, E.F., E.S. Brondizion, J.M. Tucker, M.C. da Silva-Fosberg and S. McCracken et al., 2000. Effects of soil fertility and land-use on forest succession in Amazonia. For. Ecol. Manage., 139: 93-108. DOI: 10.1016/S0378-1127(99)00337-0

Paramananthan, S., 2000. Soil of Malaysia: Their Characteristics and Identification. 1st Edn., Academy of Sciences Malaysia, Malaysia, ISBN10: 9839445065 
Parotta, J.A., 1992. The role of plantation forests in rehabilitating degraded tropical ecosystems. Agric. Ecosyst. Environ., 41: 115-133. DOI: 10.1016/0167-8809(92)90105-K

Parotta, J.A., J.W. Turnbull and N. Jones, 1997. Catalyzing native forest regeneration on degraded tropical lands. For. Ecol. Manage., 99: 1-7. DOI: 10.1016/S0378-1127(97)00190-4

Sawyer, J., 1993. Plantations in the Tropics: Environmental Concerns. 1st Edn., World Conservation Union, UK., ISBN-10: 2831701392, pp: 96.
Yetti, H., D. Belawan, A. Arifin, M.N. Mahat and A.H. Hazandy et al., 2011. Growth performance and biomass accumulation of a khaya ivorensis plantation in three soil series of ultisols. Am. J. Agric. Biol. Sci., 6: 33-44. DOI: 10.3844/ajabssp.2011.33.44

Zaidey, A.K., A. Arifin, I. Zahari, A.H. Hazandy and M.H. Zaki et al., 2010. Characterizing soil properties of lowland and hill dipterocarp forests at Peninsular Malaysia. Int. J. Soil Sci., 5: 112-130. DOI: $10.3923 /$ ijss.2010.112.130 